\title{
Herbicide Interactions in Control of Sand Shinnery Oak $^{1}$
}

\author{
C. J. SCIFRES ${ }^{2}$ \\ Associate Professor, Department of Range Science, \\ Texas AઐM University, College Station.
}

\section{Highlight}

Silvex was the most effective herbicide for reducing sand shinncry oak (Quercus havardii Rydb.) density and increasing grass production in the Rolling Plains of Texas. Combinations of silvex or 2,4,5-T with picloram controlled more sand shinnery oak than expected (synergistic) and substantially increased grass production. Picloram and 2,4-D (1:1) at $0.5 \mathrm{lb}$./acre total were additive and less effective than other phenoxy:picloram combinations. Combinations of dicamba with 2,4,5-T or silvex were usually additive.

Low-growing, shrubby oaks (Quercus spp.) or "shin oaks" infest about 8.7 million acres of Texas rangeland (Smith and Rechenthin, 1964). About 3 million acres of the High and Rolling Plains of Texas are infested with sand shinnery oak (Quercus havardii Rydb.). It has been suggested that controlling $70 \%$ or more of the sand shinnery oak in dense infestations would conserve the equivalent of 2 inches rainfall annually and leave ample brush for wildlife cover (Rechenthin and Smith, 1967).

Sand shinnery oak infests deep sands or sandy soils with shallow clay layers near the surface (Robison and Fisher, 1968). Most sand shinnery oak plants are 2 to $4 \mathrm{ft}$ tall but circular mottes of plants 6 to $12 \mathrm{ft}$ tall occur in most stands (Fig. 1). The mottes afford excellent wildlife cover. Sand shinnery oak reproduces from acorns and well-developed, lateral rhizomes. Rhizomes occur in the surface 6 inches of

${ }^{1}$ Approved by the Director, Texas Agricultural Experiment Station as technical article 9247. Received July 2, 1971.

2 The author is grateful to Jim Humphries, Pitchfork Land and Cattle Co., Guthrie, Texas who made land available for this study. Technical assistance in plot installation, maintenance and evaluation was provided by R. R. Hahn, J. H. Brock and J. C. Halifax, Texas Agricultural Experiment Station, Lubbock and College Station. Portions of the application equipment were provided by Dr. R. W. Bovey, College Station. soil and have small but viable buds along their entire length (McIlvain, 1956). The underground portion of sand shinnery oak may comprise $90 \%$ or more of the total biomass (Pettit and Deering, 1970).

Dense sand shinnery oak infestations severely reduce grass production (Fig. 1). Management of infested ranges is complicated by sand shinnery oak's toxicity to livestock (Dollahite et al., 1966; Boughton and Hardy, 1936). It is poisonous during flowering and before formation of new leaves (Robison and Fisher, 1968).

About $0.5 \mathrm{lb}$./acre of (2,4,5-trichlorophenoxy) acetic acid (2,4,5-T) or 2-(2,4,5-trichlorophenoxy) propionic acid (silvex) is used for sand shinnery oak control (Robison and Fisher, 1968). Applications from May 1 to June 1 , when sand shinnery oak is in full leaf and actively growing, are most effective. Spraying plus grazing deferment increased forage production 3 to 5 times as compared to unsprayed and deferred sand shinnery oak ranges in the Rolling Plains of Texas. However, two or three successive applications of silvex or 2,4,5-T are usually required to maximize grass production.

Repeated sprays to maximize forage production on sand shinnery oak ranges increase producer costs. Bovey et al. (1969) showed that a single application of 2,4,5-T and 4-amino-3,5,6-trichloropicolinic acid (picloram) in combination were more effective than repeated applications of 2,4,5-T alone for control of live oak ( $Q$. virginiana Mill.). The objectives of this study were a) to evaluate the influence of several herbicides and herbicide combinations for control of sand shinnery oak, b) to define interactions of herbicides in combination relative to phytotoxicity to sand shinnery oak, and c) to evaluate forage production following various levels of sand shinnery oak control in the Rolling Plains of Texas.

\section{Materials and Methods}

The experimental area was located in the Rolling Plains of northwest Texas (Gould, 1962). The area is typified by gentle slopes of Carey and Woodward fine sandy loams interspersed with valleys of deep sand. The study site was a lowland, deep sand dominated by sand shinnery oak and little bluestem ( $A n$ dropogon scoparius Michx.). The surface 6 inches was $95 \%$ sand and $3 \%$ clay with $\mathrm{pH}$ of 6.7 and about $0.2 \%$ organic matter. Significant increases in clay content were not obvious until 4 to $6 \mathrm{ft}$ deep.

The study site was aerially treated with $0.5 \mathrm{lb}$./acre 2,4,5-T in 1957 but was densely reinfested with sand shinnery oak 2 to $4 \mathrm{ft}$ tall in 1969 (Fig. 1). Sand sagebrush (Artemisia filifolia Torr.), small soapweed (Yucca glauca Nutt.) and plains pricklypear (Opuntia polyacantha Haw.) were minor components of the community. During 1969, the study site received about 11 inches precipitation. Slightly over 30 inches of rainfall were recorded in 1970. No measurable precipitation occurred from January to May, 1971.

Studies were established on May 19 and May 23 in 1969 and 1970, respectively. Sand shinnery oak was in full leaf when treated. Herbicides were applied to plots 17 by 50 or $75 \mathrm{ft}$ with a truck-mounted spraycr. All treatments were applied in a diesel oil:water emulsion (1:4) at 21 gal/acre. Treatments were replicated 4 times in randomized complete blocks in each experi- 


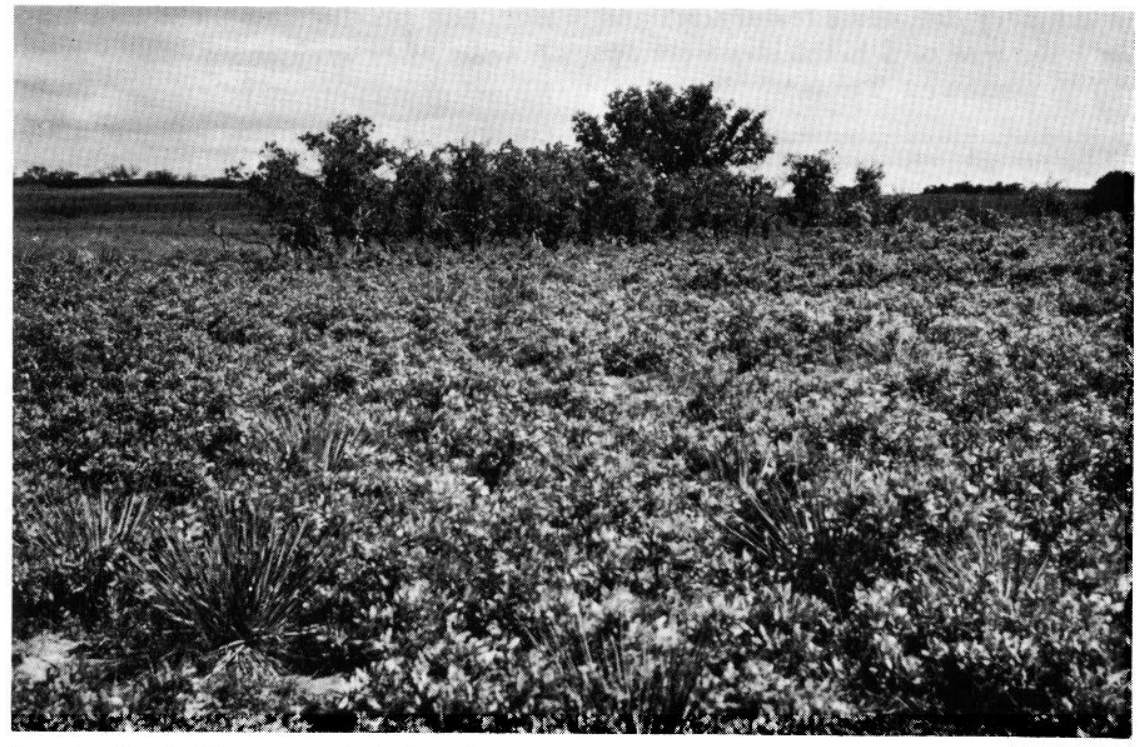

FIg. 1. Sand shinnery oak infestation in the Rolling Plains of Texas. Most of the sand shinnery oak is 2 to $4 \mathrm{ft}$ tall but large, circular mottes (background) occasionally contain plants over $10 \mathrm{ft}$ tall.

ment. Phenoxy herbicides applied at $0.5 \mathrm{lb}$./acre included 2,4-dichlorophenoxyacetic acid (2,4-D), 2,4,5-T and silvex. Each phenoxy herbicide was combined with picloram in $1: 1$ ratios to yield 0.5 or $1 \mathrm{lb}$./acre total herbicide. Silvex or 2,4,5-T was combined with 3,6-dichloro-o-anisic acid (dicamba) in 1:1 ratios totaling 0.5 and $1 \mathrm{lb}$./acre herbicide.

Four workers independently estimated the percentage of total canopy damage 30 days after herbicide application. Canopy damage included necrotic foliage plus degree of defoliation. At 1 and 2 years

Table 1. Apparent canopy reduction (\%) after 30 days and 1 year and density (thousands of live stems/acre) of sand shinnery oak after 1 and 2 years where 0.5 or $1 \mathrm{lb} . /$ acre of 5 herbicides were applied alone and in combination (1:1 ratios) in northwest Texas. ${ }^{1}$

\begin{tabular}{|c|c|c|c|c|c|c|}
\hline \multirow[b]{2}{*}{$\begin{array}{l}\text { Phenoxy } \\
\text { herbicide }\end{array}$} & \multirow[b]{2}{*}{$\begin{array}{l}\text { Herbicide } \\
\text { added }\end{array}$} & \multirow[b]{2}{*}{$\begin{array}{l}\text { Application } \\
\text { rate }\end{array}$} & \multicolumn{2}{|c|}{$\begin{array}{l}\text { Apparent canopy } \\
\text { reduction }\end{array}$} & \multicolumn{2}{|c|}{ Density $^{2}$} \\
\hline & & & $\begin{array}{l}30 \\
\text { days }\end{array}$ & $\begin{array}{c}1 \\
\text { year }\end{array}$ & $\begin{array}{c}1 \\
\text { year }\end{array}$ & $\begin{array}{c}2 \\
\text { years }\end{array}$ \\
\hline None & None & - & 0 & 0 & $70.4 \mathrm{a}$ & $89.4 \mathrm{a}$ \\
\hline $2,4-\mathrm{D}$ & None & 0.5 & 15 & 43 & $49.0 \mathrm{~b}$ & 61.1 abc \\
\hline 2,4-D & Picloram & 0.5 & 14 & 42 & $43.3 \mathrm{bc}$ & $78.9 \mathrm{ab}$ \\
\hline $2,4-\mathrm{D}$ & Picloram & 1 & 55 & 86 & 22.7 cdef & $30.3 \mathrm{bcd}$ \\
\hline $2,4,5-\mathrm{T}$ & None & 0.5 & 90 & 75 & $48.6 \mathrm{~b}$ & $66.4 \mathrm{ab}$ \\
\hline 2,4,5-T & Picloram & 0.5 & 95 & 87 & $18.6 \mathrm{def}$ & $31.6 \mathrm{bcd}$ \\
\hline $2,4,5-\mathrm{T}$ & Picloram & 1 & 98 & 97 & $5.3 \mathrm{f}$ & $8.5 \mathrm{~d}$ \\
\hline 2,4,5-T & Dicamba & 0.5 & 92 & 80 & $32.4 \mathrm{bcd}$ & $32.4 \mathrm{bcd}$ \\
\hline $2,4,5-\mathrm{T}$ & Dicamba & 1 & 95 & 87 & $32.0 \mathrm{bcd}$ & $42.1 \mathrm{abc}$ \\
\hline Silvex & None & 0.5 & 90 & 84 & 24.7 cdef & $34.0 \mathrm{bcd}$ \\
\hline Silvex & Picloram & 0.5 & 97 & 91 & 9.4 ef & $35.6 \mathrm{bcd}$ \\
\hline Silvex & Picloram & 1 & 99 & 96 & $6.5 \mathrm{ef}$ & $13.4 \mathrm{~cd}$ \\
\hline Silvex & Dicamba & 0.5 & 84 & 62 & $42.1 \mathrm{bc}$ & $53.0 \mathrm{abc}$ \\
\hline Silvex & Dicamba & 1 & 98 & 80 & $32.0 \mathrm{bcd}$ & $32.4 \mathrm{bcd}$ \\
\hline None & Picloram & 0.5 & 41 & 36 & 29.5 bcde & $59.5 \mathrm{abc}$ \\
\hline None & Dicamba & 0.5 & 21 & 11 & 79.1 a & $77.7 \mathrm{ab}$ \\
\hline
\end{tabular}

${ }^{1}$ Evaluations 30 days and 1 year after treatment represent the average of two experiments. ${ }^{2}$ Means within a column followed by the same letter are not significantly different at the $5 \%$ level. after treatment, the number of live sand shinnery oak stems were recorded in 2 , meter square, quadrats from each plot. At the same time, live sand shinnery oak stems and new grass growth were harvested to leave 1 -inch stubble, oven-dried and weighed. A sand shinnery oak stem was considered live if any green tissue was present at harvest. The study area was grazed only during October and November 1970 at 26 acre/AU.

Herbicide interactions, based on reductions in density and production of sand shinnery oak, were evaluated as described by Colby (1967). Expected reductions ("E") by the herbicide combinations were calculated from the equation:

$$
\begin{aligned}
& \mathrm{E}=\mathrm{X}+\mathrm{Y}-\frac{(\mathrm{X})(\mathrm{Y})}{100} \text { where, } \\
& \mathrm{X}=\% \text { reduction from herbicide "A" } \\
& \quad \text { at rate " } \mathrm{P} \text { " in } \mathrm{b} . / \mathrm{acre}, \text { and } \\
& \mathrm{Y}=\% \text { reduction from herbicide " } \mathrm{B} \text { " } \\
& \text { at rate " } \mathrm{q} \text { " in } \mathrm{lb} / \mathrm{acre} \text {. }
\end{aligned}
$$

Expected values were compared to observed control levels $(\overline{\mathrm{x}})$ resulting from application of herbicides $\mathrm{A}+$ $\mathrm{B}$ at $\mathrm{p}+\mathrm{q}$ lb./acre. If observed control levels were greater than expected levels, the combination was synergistic. Equality of observed and expected control indicated additivity. When observed levels were less than expected levels, the combination was antagonistic. Bovey et al. (1968) used the same basic method and accepted a difference of $20 \%$ in defoliation to assess herbicide interactions on several woody species. Colby (1967) indicated that expected and observed control could be compared with a chi-square test. In the present research, the standard deviations of mean values $\left(S_{\bar{x}}\right)$ for each variable and evaluation time were considered. A synergistic response was accepted only if observed control was equal to or greater than $\mathrm{E}+\mathrm{S}_{\overline{\mathrm{x}}}$. When $\overline{\mathrm{x}} \leqq \mathrm{E}$ - $S_{\bar{x}}$, an antagonism was accepted; and when $\mathrm{E}-\mathrm{S}_{\overline{\mathrm{x}}}<\overline{\mathrm{x}}<\mathrm{E}+\mathrm{S}_{\overline{\mathrm{x}}}$ the herbicides were considered additive.

\section{Results and Discussion}

Thirty days after application, most of the treatments containing 
Table 2. Oven-dry production of live sand shinnery oak stems (tons/acre) and grass (lb./acre) 1 and 2 years after 0.5 or $1 \mathrm{lb} . /$ acre of 5 herbicides werc applied alone or in combination (1:1 ratios) in northwest Texas. ${ }^{1}$

\begin{tabular}{|c|c|c|c|c|c|c|}
\hline \multirow[b]{2}{*}{$\begin{array}{l}\text { Phenoxy } \\
\text { herbicide }\end{array}$} & \multirow[b]{2}{*}{$\begin{array}{l}\text { Herbicide } \\
\text { added }\end{array}$} & \multirow[b]{2}{*}{$\begin{array}{l}\text { Application } \\
\text { rate }\end{array}$} & \multicolumn{2}{|c|}{ Sand shinnery oak } & \multicolumn{2}{|c|}{ Grass } \\
\hline & & & $\begin{array}{c}1 \\
\text { year }\end{array}$ & $\begin{array}{c}2 \\
\text { years }\end{array}$ & $\begin{array}{c}1 \\
\text { year }\end{array}$ & $\begin{array}{c}2 \\
\text { years }\end{array}$ \\
\hline None & None & - & $1.79 \mathrm{~b}$ & $1.22 \mathrm{bc}$ & $190 \mathrm{a}$ & $150 \mathrm{a}$ \\
\hline 2,4-D & None & 0.5 & $1.49 \mathrm{bc}$ & $1.04 \mathrm{bcd}$ & $110 \mathrm{a}$ & $325 \mathrm{ab}$ \\
\hline 2,4-D & Picloram & 0.5 & $2.56 \mathrm{a}$ & $1.80 \mathrm{a}$ & $130 \mathrm{a}$ & $170 \mathrm{a}$ \\
\hline 2,4-D & Picloram & 1 & 0.70 ef & $0.54 \mathrm{f}$ & $730 \mathrm{c}$ & $750 \mathrm{bcd}$ \\
\hline $2,4,5-\mathrm{T}$ & None & 0.5 & $0.95 \mathrm{dc}$ & 0.80 def & $210 a b$ & $410 \mathrm{~b}$ \\
\hline $2,4,5-\mathrm{T}$ & Picloram & 0.5 & $0.25 \mathrm{~g}$ & $0.52 \mathrm{f}$ & $110 \mathrm{a}$ & $410 \mathrm{~b}$ \\
\hline $2,4,5-T$ & Picloram & 1 & $0.04 \mathrm{~g}$ & $0.16 \mathrm{~g}$ & $1010 \mathrm{~d}$ & $1040 \mathrm{~d}$ \\
\hline $2,4,5-T$ & Dicamba & 0.5 & $1.79 \mathrm{~b}$ & $0.63 \mathrm{ef}$ & $200 \mathrm{a}$ & $470 \mathrm{bc}$ \\
\hline $2,4,5-\mathrm{T}$ & Dicamba & 1 & $1.25 \mathrm{~cd}$ & $0.59 \mathrm{f}$ & $140 \mathrm{a}$ & $760 \mathrm{bcd}$ \\
\hline Silvex & None & 0.5 & $0.40 \mathrm{fg}$ & $0.55 \mathrm{f}$ & $720 \mathrm{c}$ & $380 \mathrm{ab}$ \\
\hline Silvex & Picloram & 0.5 & $1.25 \mathrm{~cd}$ & $0.74 \mathrm{f}$ & $600 \mathrm{c}$ & $600 \mathrm{bc}$ \\
\hline Silvex & Picloram & 1 & $0.17 \mathrm{~g}$ & $0.12 \mathrm{~g}$ & $600 \mathrm{c}$ & $825 \mathrm{~cd}$ \\
\hline Silvex & Dicamba & 0.5 & $1.14 \mathrm{~cd}$ & 0.92 cde & $240 \mathrm{~b}$ & $320 \mathrm{ab}$ \\
\hline Silvex & Dicamba & 1 & $0.69 \mathrm{ef}$ & $0.58 \mathrm{f}$ & $600 \mathrm{c}$ & $560 \mathrm{bc}$ \\
\hline None & Picloram & 0.5 & $1.20 \mathrm{~cd}$ & $1.27 \mathrm{~b}$ & $185 a$ & $100 \mathrm{a}$ \\
\hline None & Dicamba & 0.5 & $1.83 \mathrm{~b}$ & $0.61 \mathrm{ef}$ & $200 \mathrm{a}$ & $300 \mathrm{a}$ \\
\hline
\end{tabular}

${ }^{1}$ Evaluations 1 year after treatment represents the average of two experiments. Means within a column followed by the same letter are not significantly different at the $5 \%$ level.

silvex and 2,4,5-T damaged over $90 \%$ of the sand shinnery oak canopy (Table 1). These evaluations compare initial phytotoxicity of the herbicidal sprays. However, such reductions may not accurately serve as indices of control the season following treatment. The least effective treatments in initially reducing the sand shinnery oak canopy were 2,4-D, 2,4-D plus picloram, picloram, and dicamba. In all cases except where 2,4-D was combined with picloram at $0.5 \mathrm{lb}$./acre of each, recovery of foliage was cvident 1 year after treatment.

Combinations of low rates of 2,4-D and picloram were no more effective in reducing sand shinnery oak density than $0.5 \mathrm{lb}$./acre of either herbicide applied alone (Table 1). Two years after application, 2,4-D, picloram, or 2,4-D plus picloram at $0.25 \mathrm{lb}$./acre of each herbicide did not significantly reduce the density of sand shinnery oak stems as compared to the untreated areas.

Sand shinnery oak production in plots receiving 2,4-D or the low rate of 2,4-D plus picloram was not reduced at either evaluation time (Table 2). Sand shinnery oak pro- duction was reduced by picloram applied alone only on plots evaluated 2 years after treatment. However, density and production of sand shinnery oak on plots treated with the combination at $0.5 \mathrm{lb}$./ acre of 2,4-D and picloram were reduced at both evaluation times (Tables 1 and 2).

Observed density reduction was equal to expected levels with 2,4-D plus picloram resulting in an additive effect (Table 3). An additive effect also resulted when sand shin- nery oak production was considered 1 year after treatment. The combination was effective enough to be considered synergistic using production values 2 years after treatment. In every case, control of sand shinnery oak from the combination of 2,4-D plus picloram at $0.5 \mathrm{lb}$./acre total herbicide was equivalent to control from $0.5 \mathrm{lb}$./acre of silvex applied alone.

Grass production was not increased at 1 or 2 years following the application of $0.5 \mathrm{lb}$./acre 2,4-D, picloram, or 2,4-D plus picloram as compared to untreated plots (Table 2). However, grass production was increased 3 to 5 times by a single application of 2,4-D and picloram combined to give $1 \mathrm{lb}$./acre.

Initial canopy damage indicated sand shinnery oak to bc more susceptible to $2,4,5-\mathrm{T}$ than to $2,4-\mathrm{D}$ (Table 1). However, 2,4,5-T was no more effective than 2,4-D in reducing sand shinnery oak density. High densitics 1 year after treatment with $2,4,5-\mathrm{T}$ were due to new sprouts. Sprays of 2,4,5-T evidently damaged aerial sand shinnery oak stems but were not lethal to underground organs. This released vegetative buds from apical dominance and allowed resprouting. These observations substantiate the need for retreatment with $2,4,5-\mathrm{T}$ as indicated by Robison and Fisher (1968).

Since most of the new brush growth was less than 6 inches tall 2 years after treatment with $2,4,5-T$,

Table 3. Interaction of $0.25 \mathrm{lb}$./acre of $2,4-\mathrm{D}, 2,4,5-\mathrm{T}$ or silvex with 0.25 lb./acre of dicamba or picloram in reducing density and production of live sand shinnery oak stems 1 and 2 years after treatment in northwest Texas. 1

\begin{tabular}{|c|c|c|c|c|c|c|}
\hline \multirow{3}{*}{$\begin{array}{c}\text { Measurement } \\
\text { and } \\
\text { herbicide }\end{array}$} & \multicolumn{6}{|c|}{ Herbicide } \\
\hline & \multicolumn{2}{|c|}{$2,4-\mathrm{D}$} & \multicolumn{2}{|c|}{$2,4,5-T$} & \multicolumn{2}{|c|}{ Silvex } \\
\hline & $\begin{array}{c}1 \\
\text { Year }\end{array}$ & $\begin{array}{c}2 \\
\text { years }\end{array}$ & $\begin{array}{c}1 \\
\text { Year }\end{array}$ & $\begin{array}{c}2 \\
\text { years }\end{array}$ & $\begin{array}{c}1 \\
\text { Year }\end{array}$ & $\begin{array}{c}2 \\
\text { years }\end{array}$ \\
\hline \multicolumn{7}{|l|}{ Density } \\
\hline $\begin{array}{l}\text { Dicamba } \\
\text { Picloram }\end{array}$ & $\overline{A d}$ & $\overline{A d}$ & $\begin{array}{l}\text { Ad } \\
\text { Sy }\end{array}$ & $\begin{array}{l}\text { Ad } \\
\text { Sy }\end{array}$ & $\begin{array}{l}\text { Ad } \\
\text { Ad }\end{array}$ & $\begin{array}{l}\text { Ad } \\
\text { Ad }\end{array}$ \\
\hline \multicolumn{7}{|l|}{ Production } \\
\hline $\begin{array}{l}\text { Dicamba } \\
\text { Picloram }\end{array}$ & $\overline{A d}$ & Sy & $\begin{array}{l}\text { An } \\
\text { Sy }\end{array}$ & $\begin{array}{l}\text { Ad } \\
\text { Sy }\end{array}$ & $\begin{array}{l}\text { An } \\
\text { Sy }\end{array}$ & $\begin{array}{l}\text { An } \\
\text { Sy }\end{array}$ \\
\hline
\end{tabular}

1 "Ad" indicates additivity, "An" indicates antagonism and "Sy" indicates synergism with herbicide combinations. 
sand shinnery oak production was reduced by about 50\% when compared to untreated plots (Table 2). Grass production more than doubled 2 years after 2,4,5-T application.

Combinations of 2,4,5-T and picloram were more effective in controlling sand shinnery oak than either herbicide applied alone (Tables 1 and 2). Green foliar tissues were almost eliminated by 30 days after application of picloram combined with $2,4,5-\mathrm{T}$ at $0.5 \mathrm{lb}$./ acre of each herbicide (Table 1). The combination was synergistic using either density reductions or reduced sand shinnery oak production as indices. More grass was produced on plots where the high rate of 2,4,5-T plus picloram was applied than from any other treatment. Due to dry growing conditions, no new grass seedlings were noted in any plot. All production increases resulted from release of established grass clones.

Sand shinnery oak control from dicamba combined with 2,4,5-T was equal to control expected 2 years after application resulting in additive reductions in sand shinnery oak density and production (Table 3). Additivity of this combination was suggested by Scifres and Hoffman (1972) from results with honey mesquite (Prosopis glandulosa Torr. var. glandulosa) in Rolling Plains of Texas. However, grass production was statistically equivalent to plots treated with the same rates of 2,4,5-T plus picloram.

Silvex was more consistent than other herbicides applied alone for control of sand shinnery oak regardless of experiment, evaluation time, or evaluation method. Grass production was higher a year after application of $0.5 \mathrm{lb}$./acre silvex than where other herbicides were applied alone (Table 2). Less sand shinnery oak regrowth occurred on silvex-treated plots 1 and 2 years after treatment than on plots treated with 2,4,5-T.

Density reductions from silvex combined with picloram were similar to those from $2,4,5-\mathrm{T}$ and pic- loram (Table 1). The combination was not effective enough to be classed as synergistic when density reduction was considered (Table 3 ). However, when evaluated on the basis of production, observed control from the silvex/picloram combination was higher than expected control. Synergistic action may occur through the same physiological mechanism operative when 2,4,5-T and picloram is applied to live oak. Foliar absorption of picloram was augmented by 2,4,5-T (Baur et al., 1971). Two years after treatment, grass production where sand shinnery oak was treated with silvex/ picloram combinations was similar to that from plots treated with combinations of 2,4,5-T and picloram (Table 2).

Silvex combined with dicamba reduced densities in an additive fashion (Tablc 3) and controlled about the same amount of sand shinnery oak as did the combination of 2,4,5-T and dicamba (Table 1). However, observed sand shinnery oak production was greater than expected (Table 3) and the combination was less effective than silvex alone. Interactions of dicamba with silvex or with $2,4,5-\mathrm{T}$ on sand shinnery oak indicate the need for more research to clarify performance of dicamba/phenoxy herbicide combinations on woody plants.

No treatment effectively prevented regrowth of sand shinnery oak. Fewer new stems were recorded where silvex or silvex plus picloram were applied than in other plots. However, retreatment would probably be necessary within 3 to 5 years after initial application of 2,4,5-T or silvex whether applied alone or in combination with other herbicides.

Since sand shinnery oak infests sandy soils, total control would probably not be advisable. In light of these data, the $70 \%$ control level advised by Rechenthin and Smith (1967) would be satisfactory initially if grass were established to stabilize sand shinnery oak sites. Retreatment schedules for mainte- nance of sand shinnery oak control would depend upon livestock management programs devised for infested rangelands.

\section{Literature Cited}

Baur, J. R., R. W. Bovey, R. D. Baker, AND I. RILEY. 1971. Absorption and penetration of picloram and 2,4,5-T into detached live oak leaves. Weed Sci. 19:138-140.

BOUghton, I. B., AND W. T. HARDY. 1936. Oak poisoning in range cattle and sheep. J. Amer. Vet. Med. Assoc. 89:157-162.

Bovey, R. W., F. S. Davis, AND H. L. Morton. 1968. Herbicide combinations for woody plant control. Weeds 16:332-335.

Bovey, R. W., S. K. Lehman, H. L. Morton, AND J. R. BAur. 1969. Control of live oak in South Texas. J. Range Manage. 22:315-318.

Colby, S. R. 1967. Calculating synergistic and antagonistic responses of herbicide combinations. Weeds 15: 20-22.

Dollahte, J. W., G. T. Housholder, AND B. J. CAMr. 1966. Oak poisoning in livestock. Texas Agr. Exp. Sta. Bull. 1049. 8 p.

Gould, F. W. 1962. Texas Plants. A chccklist and ecological summary. Texas Agr. Exp. Sta. MP-585. 112 p.

McIlvain, E. H. 1956. Shinnery oak can be controlled. Proc. So. Weed Conf. 9:95-98.

Pettit, R., AND D. DeEring. 1970. Sand shinnery oak control in noxious brush and weed control research highlight, 1970. ISCALS special rep. 40:8.

Rechenthin, C. A., ANd H. N. Smith. 1967. Grassland Restoration. V. Effect on yield and water supply. U.S. Dep. Agr., Soil Cons. Ser. Unnumbered bulletin. Temple, Texas. $46 \mathrm{p}$.

Robison, E. D., AND C. E. Fisher. 1968. Chemical control of sand shinnery oak and related forage production. Tex. Agr. Exp. Sta. PR-2583 in Brush Research in Texas, 1968:5-8.

Scifres, C. J., and G. O. Hoffman. 1972. Comparative susceptibility of honey mesquite to dicamba and 2,4,5-T. J. Range Manage. 25:143146.

Smith, H. N., and C. A. Rechenthin. 1964. Grassland restoration. The Texas brush problem. U.S. Dep. Agr., Soil Cons. Serv. Temple, Texas. 